IGOR STIPIĆ ${ }^{1}$

CONSTRUCTING "THE PEOPLE"

Citizen populism against ethnic hegemony in Bosnia-Herzegovina in the light of the 20132014 protests

DOI: 10.18030/SOCIO.HU.2017EN.90

\title{
ABSTRACT
}

This article, essentially following the contributions of Gramsci and Laclau on hegemony and populism (a non-normative view), analyzes the possibilities for Bosnian-Herzegovinian (BiH) society to challenge its predominantly unaccountable and authoritarian political structures, taking as a point of departure the 20132014 outburst of protests and social mobilization. The analysis is situated in a context of specific cultural and social conditions marked by the ideological hegemony of ethnic discourse. In this sense, unprecedented levels of solidarity among BiH ethnic societies by signaling an end to chronic depolitization that had plagued this socio-political space ever since the transition to democracy, served as an opportunity for the construction of a new universal signification that could break with the coherence of the existing discourse and offer an antagonistic frontier different than the one characterized by the ethnic question. This incipient appearance of a social project rivaling deeply entrenched ethnic democracy, appearing in the times of (minor) organic crisis, offered, mainly through the logic of displacement of an already established political frontier, a new perspective on the BiH political scene. This war of position, in our view, provides fertile ground for the development of what could be defined as citizen populism. As such, by taking the BiH citizens, the system outcasts par excellen$c e$, to the center of the political stage, social movements offer a chance to replace the well-established notion of ethnic subjects with that of fully-fledged citizens. Additionally, this article considers the problematique of building bonds of equivalences in both socially and ethnically heterogeneous social movements that demand accountability from existing structures, while rejecting its own projection via political society, a sin qua non for representation of demands.

Keywords: Bosnia-Herzegovina, hegemony, populism, social movements.

1 Research Fellow at iASK (Institute of Advanced Studies in Köszeg, Hungary) 
IGOR STIPIĆ

\section{CONSTRUCTING “THE PEOPLE” \\ Citizen populism against ethnic hegemony in Bosnia-Herzegovina \\ in the light of the 2013-2014 protests}

\section{INTRODUCTION: IDEA, METHODOLOGY AND ORGANIZATION}

After decades of political lethargy, citizens of Bosnia and Herzegovina $(\mathrm{BiH})$ rose in protests that became known as the most significant uprising in the short independent and democratic history of this country. The uprisings followed no particular stages of development. As such, in a matter of hours after the beginning of country-wide demonstrations, it seemed that BiH was about to go to the streets. This came to be considered as a source of horror for ethno-national elites, exemplified in the destruction of government buildings and people demanding the right to have a future, as it was covered by the media. The prospect of citizen solidarity, seemingly reaching the forgotten unity of three ethnic groups, symbolized a real earthquake to the well-known narrative of the trans-historical and a-historical hatred overseeing the country. At such times, the new narrative entered the political space of the political system, and embodied it, in the view of the political elites. With this in mind, the narrative of people crossing the well-entrenched borders of ethnic hatred brought down the ethnically painted facades of this polis, in which citizens are held as prisoners of the political class.

Moreover, once contextualized in the space of BiH Dayton politics, the issue of narratives and construction of "the people" embodies the most important aspect of the protests. In this sense, the present article, besides explaining the appearance, developments and results of the protests, will have as its main concern the struggle of conflicting narratives over the constitution of the BiH political subject. By analyzing emerging discourses, I aim to expose how the subjectivity or perception of the world can be constructed, maintained or debated in the public space, taking as a case study the 2013-2014 protests in BiH. By analyzing competing discourses, based on ethno-national and citizen concerns, we aim to see how they intend to create a distinct conception of "the people".

Research was carried out by using methods of on-site participant observation in the cities of Sarajevo and Mostar during the Bebolucija and Tuzla Uprisings. This implied informal talks with participants of the protests, and interviews with activists from Mostar, Banja Luka and Sarajevo. Also, this was complemented with content and discourse analysis of publicly available media and protest material that emerged during the period of social mobilizations.

Additionally, it seems important to think of the BiH case in relation to the larger context of Central and Eastern Europe. The dominant character of what came to be perceived as unsuccessful democratic transitions, resulting in a crisis of institutionalism and rising social inequality, have in some cases opened the doors to 
various populist and authoritarian options (in $\mathrm{BiH}$, this happened th the very establishment of democracy) inside mainstream public discourse.

The article is organized as follows. The first part explains the theoretical framework used for the analysis. The second part discusses the construction of ethno-national hegemony in BiH after the end of the civil war in 1995. The ensuing part deals with questions of the rise of a new competing citizen narrative, while also analyzing the resistance of the ethno-national discourse. Finally, there will be attempts to explain the downfall of the protests and the continued dominance of an ethno-national narrative in this polis.

\section{THEORETICAL FRAMEWORK}

The theoretical framework is constructed by combining models of discourse theory (Laclau-Mouffe in Jorgensen-Phillips 2002), hegemony (Gramsci in Bates 1975), and populism (Laclau 2005). First and foremost, discourse theory asserts how social reality is principally constructed through discourses. This socially accepted "reality" is what Laclau defines as objectivity, claiming that "discourse is the primary terrain of the constitution of objectivity as such" (ibid: 68). Thus, rather than having social obviousness defined a-priori, social knowledge, beliefs and identities derived from them are fully discursive. Consequently, as the meaning of an imagined whole we usually refer to is "never completed or total" (Laclau-Mouffe in Jorgensen-Phillips 2002: 38), "the society" - a primary object of social knowledge and invoked totality - turns into a site of struggles to create and fix meaning. Consequently, contestns over names and definitions of totality, such as regional belonging and its limits, identity, class, nation or other demarcations are not necessarily as durable or eternal as some may assert, but belong to unending "struggles over the monopoly of the power to make people see and believe" (Bourdieu, 1991: 221). Therefore, discourses, due to their ability to make and unmake groups, hold the key to understating the constructed nature of what is understood as a legitimate definition of the social world.

Moreover, the production of identities and the social reality that accompanies them, due to the already mentioned impossible social fullness, requires a radical investment into this specific conceptual creation. Thus, the meaning of totality (i.e. society, people, nation, class) can only be grounded a-posteriori as it is produced by the means of symbols and through rhetoric, articulation and naming around certain nodal points which become "privileged signs around which a discourse is organized" (Laclau-Mouffe in Jorgensen-Phillips 2002: 27). In this sense, "symbolic power is a power of constructing reality" (Bourdieu 1991: 166) as it is "the symbolic framework of a society that sustains a certain regime" (Lefort in Laclau 2005: 166). Thus, "symbols are the instruments par excellence of "social integration: as instruments of knowledge and communication, they make it possible for there to be a consensus on the meaning of the social world, a consensus which contributes fundamentally to the reproduction of the social order" (Bourdieu 1991: 166).

Furthermore, these signs, or signifiers, are essentially empty as they have no specific content which is conceptually established and unchangeable. Rather, the meaning of the social established discursively "can never be ultimately fixed" (Laclau-Mouffe in Jorgensen-Phillips 2002: 24) and it is essentially contingent - possible but not necessary. In this way, signifiers (nodal points, privileged signs), besides being empty, are also floating, implying that the battle over determination of their meaning by various discourses is never finished. Thus, as 
social totality remains nothing more than an imagined identity, words given to it, such as "people", "country", or "nation", from being objectified through discourses, represent both empty and floating signifiers, and in this way become sights of political struggle. In this sense, the very act of naming, representing an embodiment of reality, is central for creation of objectivity because it crystalizes the meaning of the unknown and fuzzy world by "diffusing a state of feeling which had not previously found any form of discursive representation" (Laclau 2005: 45).

Additionally, the act of naming, or a conceptual grasping of social totality, inevitably involves building a frontier that differentiates imagined totality from something other than itself (Laclau 2005). In other words, to achieve its fullness, an imagined totality has to introduce an excluded element, a "constitutive exteriority" (Staten in Mouffe, 2005), which becomes an element "that the totality expels from itself in order to constitute itself" (Laclau, 2005: 70). In this way, totality is established only vis-à-vis an excluded element, as all other differences can only find internal cohesion in their common rejection towards the constitutive exteriority. As Laclau (2005: 70) notes, "it is through the demonization of a section of the population that a society reaches a sense of its own cohesion". In this sense, "identity is always relationally organized; the subject is something because it is contrasted with something that it is not" (Laclau-Mouffe in Jorgensen-Phillips 2002: 43). This act of creating a frontier between "us" and "them" represents a closure, and it is a sine qua non of having totality as such, because otherwise, differences that keep existing inside of this totality would be insurmountable. Essentially, "without some kind of closure, however precarious it might be, there would be no signification and no identity" (Laclau 2005: 70). Likewise, the construction of a frontier plays a constitutive role for the ideological makeover of any identity as it reveals how identity is nothing more but an "identification with a subject's position in a discursive structure" (Laclau-Mouffe in Jorgensen-Phillips 2002: 43).

Furthermore, both the temporality and contingency of objectivity are masked through hegemony which arises as "some fixations of meaning become so conventionalized that we think of them as natural" (LaclauMouffe in Jorgensen-Phillips 2002: 26). Simply put, hegemony is related to the creation of social consensus over the meaning, as "no social fullness is achievable except through hegemony" (Laclau 2005: 116). As such, arising as a dominant consensual vision and the division of the social world, hegemonic intervention makes subjects, rather than being fragmented between various discourses, over-determined by a particular vision of social reality. The concept of hegemony demonstrates how "the production of meaning is a key instrument for the stabilization of power relations" (Laclau-Mouffe in Jorgensen-Phillips 2002: 32), as it is the over-determination of subjects that makes other possible narratives seem impossible, exactly due to its ability to represent itself in the name of totality. In this sense, Gramsci (in Bates 1975) affirms how the battle in superstructure is basically a battle for the control over civil society - a marketplace of ideas and public opinion, where culture, ideology and symbols play a central role.

Nevertheless, even hegemonic creations suffer from their constitutive and contingent character, which even when hidden for the time being implies a closure that is only temporary and is thus always in danger of being reconstituted and invaded by other discourses. As Laclau (2005: 226) notes, "history is rather a discontinuous succession of hegemonic formations that cannot be ordered by a script transcending their contingent meaning". In this sense, official historiographies, unquestionable at certain periods, can at other 
times be contested, allowing for a counter-vision, one that probably had stayed dormant for prolonged period of time, to take its place and gain momentum in the creation of other types of objectivity. Mouffe and Laclau (in Jorgensen-Phillips 2002: 27) denominate these excluded possibilities as the "field of discursivity", which "is a reservoir for the surplus of meaning".

This change of narrative, or troubles in superstructure, usually takes place during moments that Gramsci (in Bates 1975) defines as organic crisis. Organic crisis, according to our understanding, appears once a social upheaval pairs with deep economic, social and political issues that overwhelm certain social spaces. When the system encounters troubles in performing its main functions (providing food, security, employment, hope in the future, etc.) people are more likely to reject previous objectivities, abandon dominant parties and thus stop believing in previously unquestionable "truths". At such times, a systemic dislocation appears, making people, due to the inherent human need for sense of perception of time, space and history, more willing to accept new meanings of the social - which can be delivered by competing discourses able to project a horizon of a new totality. As this happens, there is a radical break from previous formations and an emergence of the new historical period can take place.

Being at the root of any populist, anti-institutional outburst, the resulting chasm between the people (firstly emerging as crowds) and power (political elites and state institutions) opens up a space for both discursive and political alternatives. In this sense, as certain regimes demonstrate themselves unable to contain the excess of demands coming from the people within the existing institutional system, dominant discourses may lose their ability to totalize social reality and the name of "the people". If this process unfolds, a dialectic vision of a unified history of a historical bloc is unlikely to be maintained, making existing social logics incompatible with previously dominant narratives. For this reason, "people", as a historical and political subject, may require a new conceptualizing framework. As such an opportunity for politics arises, populist forces - simply meaning those invoking, challenging or creating the name of "the people" (filling its emptiness) - can contest and even subvert previous systems of beliefs, offering alternative discourses by reconstructing the name around a new popular core, thus constructing a new social totality. Therefore, populism, a political logic emerging at times of deep institutional crisis, essentially breaks the coherence of existing discourses as it contends the naming of social totality and consensus over its meaning. Lying at the heart of politics, and being essentially nothing more than a practice of naming and constructing "the people" (answering the essential question "Who are the people?"), populism appears as simply one of the ways of constituting the unity inside of groups (Laclau 2005). In this sense, "constituting 'the people' [...] reveals representation for what it is: the primary terrain of constitution of social objectivity" (Laclau 2005: 68).

Nevertheless, new visions of organizing society still have to enter in struggle over the "true" meaning with the old ones. This battle for meaning, a "battle for articulating social majorities around certain discourses" (Hall in Galvan 2011: 130), a battle for constituting objectivity, or a logic of displacement of political frontiers is what Gramsci defines as a "war of position". As such, the frontiers are never immobile, but are changing in the constant battle over inscription of meaning into the "empty signifiers" and movement of "floating signifiers". It is here where the political game of constructing "the people" essentially takes place. 
In a nutshell, discursive theory affirms that the political field is "the site par excellence in which agents seek to form and transform visions of the world and thereby the world itself" (Bourdieu 1991: 26). The political struggle consists of creating knowledge of the social world, entailing a constant process of construction, deconstruction and reconstruction of categories of perception of our social reality. Therefore, "political logics are related to the institution of the social" (Laclau 2005: 117).

\section{Hegemony of Ethno-National Discourse in Bosnia-Herzegovina}

During the organic crisis (i.e. skyrocketing inflation and unemployment) that seriously affected all communist regimes in Eastern Europe, Yugoslavian space entered the process in which previous objectivities ceased to function for most of its citizens. In this ambiance, resulting in fear of both an unstable present and an unpredictable future, ethno-national populists emerged as a political force able to harvest existing uncertainties, crystalizing that fuzzy reality into a discourse which offered a sense of both historical continuity and a better future. As such, ethnic populism essentially signified a "way to fill the void left behind by the failure, powerlessness and perceived incapability of other ideologies, political projects and programs to fulfill the hopes of the people" (Hobsbawm 1993: 158). As with any populist creation, it represented a "utopia of those who lost faith in other programs, or have lost the support of previous political and social stabilities" (ibid: 158). At such times of crisis, ethno-national populism achieved moral, intellectual and political pre-eminence, converting fragmented subjects into ones over-determined by its specific type of objectivity. Consequently, ever since the early 1990s, BiH citizens had its consensual meaning of the social world discursively created by the means of what can be denominated as ethno-national populism.

In this sense, $\mathrm{BiH}$ as we know it today was established in 1995 by the Dayton Peace Agreement (DPA) that ended the three-year-long civil war. Following this, the DPA divided BiH into two entities: the Federation of Bosnia and Herzegovina ( $\mathrm{FBiH}$, divided into ten cantons with a Bosniak-Muslim and Croat majority) and the Republic of Srpska (RS, centralized with a Serb majority). Annex four of this agreement, also serving as the constitution, by making constitutive peoples (ethnic groups) into constitutional bearers of the new democratic society, overwhelmingly emphasizes the primacy of the collective (ethnic) over individual rights. As such, by understanding competition between different ethnic groups as the only real embodiment of the $\mathrm{BiH}$ political game, the DPA has created a type of citizenship according to which a citizen once stripped of his ethnic identification becomes a concept emptied of meaning and actual political agency. For example, citizens can only elect representatives of their own groups for the offices of the Presidency and the House of Peoples (parliament). Likewise, citizens who identify themselves as something other than constitutive peoples (i.e. Jew, Roma, Slovak, Ukrainian, Bosnian and/or Herzegovinian) cannot run for office. Such an absurdity was denounced by the decision of the European Court of Human Rights which, in the case of Sejdic-Finci, ordered (unsuccessfully) this constitutional specificity to be reverted. Correspondingly, in BiH, citizenship, as a link between individuals and the state, is largely understood through the prism of ethnicity (Guzina 2005: 227). As Mujkic (2016) notes, in this situation, a concept of individual citizenry is an abstract and "un-real" notion, merely formal and administrative. Thus, in $\mathrm{BiH}$, the failure to develop a universalistic and republican notion of citizenship, and its complete subordination to the nationalist notion, makes citizenship itself into some pre- 
political fact unaffected by the formation of political opinion and will of the citizens themselves (Habermas, 1996).

Unsurprisingly, the frontier to be built by ethno-populist discourse in the post-Yugoslav space of BiH, on which a whole ideological content of identity depends, made strict and insurmountable lines of particular homogenous ethno-religious communities. This type of frontier, due to its exclusivity, resulted in an authoritarian and anti-pluralist character. Following this, in celebration of the particularism of a supposed national culture, one to be principally defined by religion, ethno-national populism established strict limits of community and reduced the plurality usually present in populist movements into a singularity of ethnicity. As such, it found its constitutive exteriority in other ethnic groups living in the BiH space, constructing a type of border which at times led to practices of ethnic cleansing or even genocide. This new imagined social totality resulted in subjects defined by a strong nationalism, accompanied by powerful national social majority movements that, as a result of their pursuit of a clean and healthy society, led to the logic of authoritarian collectivism. In this environment, empty signifiers of "nation" or "people", came to be exclusively related to ethnic identities, disabling the opportunity for them to be extended over inter-ethnic boundaries.

Furthermore, ethno-national discourse, once it had won the contest of being the only legitimate incarnation of BiH social reality, would quickly manage to turn into a hegemonic narrative, creating a particular symbolic framework that would sustain it in this new historical period. In order to ensure the continuous exercise of hegemony, the maintenance of social consensus, and the credibility of ethnic social objectivity, Ethno-Bureaucratic Patrimonialism (EBP) ${ }^{2}$ (Stipic 2017) had to focus on a reproduction of its particular discourse because the "social formation which did not reproduce the conditions of its production at the same time as it was produced was doomed to die" (Marx in Althusser 1984: 1). This reproduction of conditions of production of such a particular social objectivity was essentially assured by the complete domination of what Althusser (1984) terms "Ideological State Apparatuses" (ISAs: educational, religious, cultural and political institutions) by each ethnic regime inside of $\mathrm{BiH}$.

First and foremost, in $\mathrm{BiH}$, the ISA has ensured, through the complete control it exercises over the educational system, the very first institution a child interacts with, and enormous power over the socialization of its future citizens. Especially in societies that face divisions and inter-group tensions, education is a powerful potential source of both integrationist and dis-integrationist forces. In the case of $\mathrm{BiH}$, all children study under three different educational programs, and if by some "mistake" the school is attended by students from different ethnic groups, these are kept separate from each other in the infamous invention of "two schools under one

2 Ethno Bureaucratic Patrimonialism (EBP) is the term I use to define a type of political regime established in BiH during what is normally considered as the second transition to democracy. In this sense, EBP represents a political regime inside of which political behaviour is overdetermined by: 1) the absolute hegemony of ethno-national objectivity of the social world; and 2) absolute patrimonialization of the bureaucratic public office, which is the main employer in the economy. While ethnonational hegemony leads to a conversion of what are supposed to be citizens into politically instrumentalized subjects, ensuring an absolute monopoly of ethno-national parties over political life, patrimonialization of the public office, leading to the patrimonialization of the state itself, has the power to discipline citizens in such a way that it turns an impersonal relationship between independent voters and politicians into a disciplined relationship between patrons and their clients. The exercise of political power, derived nominally from the people, becomes in such environment entirely discretionary, as rules and limits are imposed directly by the political administrators. (Stipic 2017: 102). 
roof". ${ }^{3}$ Unsurprisingly, the research called "Education in BiH: What do we teach the children?" (Husremović et al. 2017), has demonstrated that the textbooks of the national group of subjects (history, religion, language, geography) are "equally directed at promoting one people, one part of the country, one religion, one cultural heritage, this being the one to which the majority of population on a particular territory on which the books are used belongs" (ibid: 178-179). Thus, in BiH, an official history propagated through educational institutions becomes an important disintegrationist mechanism in the hands of the ruling ethno-elites. Besides, an attempt by ethno-linguistic-intellectuals to make the Bosnian, Serbian and Croatian languages (which literally contain fewer differences than various Italian dialects or many versions of Spanish in Latin America) strictly differentiated and quasi unintelligible to one another, clearly demonstrates how "in the essence of language nationalism we find issues of power, status, politics and ideology, and not of communication or even culture" (Hobsbawm 1993: 121). Similarly, a large proportion of the print media, controlled to a great extent by the main ethno-national parties, serves the purpose of paying lip service to the defense of ethno-national "truths", thus leaving little or no space for other interpretations (Perisic 2010). Finally, Catholicism, Islam and Orthodoxy, three dominant monotheistic religions in the country, which are also the main source of differences between existing ethnic groups and a "hallmark of nationhood in the Balkans" (Perica 2002), are quite successfully misused (due to their possession of universal truths and monopoly on morality), with or without the approval of the religious leaders, to emphasize the clear borders and "enormous" differences that exist between Croats, Bosniaks and Serbs (Abazovic 2006).

Besides, BiH political elites are involved, through public discourses, in maintaining "civil wars of memory" (Kuljic, 2005). By making the word "threat" into the most significant embodiment of BiH reality, ethnopoliticians foster an environment in which constant dangers to and conspiracies against "our" survival become the main news of the day. To that end, the empty signifier of "vital national interest", (mis)used for any type of manipulation, converts every political game in $\mathrm{BiH}$ into a zero-sum game between existing ethnic groups. This leads to what Mujkic (2006: 66) defines as ethnopolitics that in the case of $\mathrm{BiH}$, represents a "political context in which citizenship of a person is predisposed by his or her kinship, his or her belonging to this or that group of common, or more explicitly by his or her blood origin". In this sense, ethnopolitics and the hegemony of the ethnic, by superimposing the notion of particularism of cultural community, bound together by origin and fate over the notion of universalism present in an egalitarian legal community (Habermas, 1996), effectively empties the BiH state of its citizens.

\section{CONTEXTUALIZING PROTESTS}

$\mathrm{BiH}$ society was never characterized by a serious protest culture. Due to the specific type of historically structured learning (O'Donnell, 1994), it passed from the Middle Ages into the Ottoman period, later to the Kingdom and Federation of Yugoslavia, to finally transition to democracy through the act of war fought for nationalistic and not democratic ideals. It lacks any kind of enlightenment period in its history. In this sense, its

3 "Two schools under one roof" represents a particular BiH invention in which students of various ethnic groups that live together in a certain area come to be physically segregated into different classrooms and timeslots of the same school building they share, all with the aim that their interaction is maximally reduced. 
recent transition towards democracy is stripped of any kind of deeper sense of democratic ideals and culture, being rather dominated by the ghosts of an authoritarian past (and present). Thus, in the first 15 years of Dayton, few progressive protests took the streets. Among the few that appeared, it would be important to take into account the 2008 protest in Sarajevo against street violence (after the murder of a teenager), the 2009 protest of Tuzla University students (after a corrupted process of scholarship selection), and the 2012 Save Picin Park (Park je nas) protest in Banja Luka (after plans for the construction of a mall in a popular park). In this sense, instead of appearing as organized social movements, demonstrations of dissatisfaction tend to arise for ad-hoc reasons, exploding almost out of nowhere and tending to build themselves from scratch.

In 2013 and 2014, it was barely different. As such, Bebolucija itself was completely free of any serious organizational maneuvering and rather exemplified yet another (the most massive up to date) spontaneous outburst of dissent. In this sense, Bebolucija effectively started when one activist made a post on Facebook (on June 5,2013 ) in which he declared his outrage with the failure of MPs to pass a law allowing newborns to obtain their citizen identification number (JMBG). ${ }^{4}$ The parliamentary procedure was stalled when the Serb representatives demanded a clear differentiation in ID numbering between respective $\mathrm{BiH}$ entities, refusing to proceed with the law they denounced as threatening their "vital national interest". As Zoran Ivancic (2013), an activist who started the protest, claimed: "First to respond to my post was a friend of Belmina's parents [...] Once I got back at 11am and checked Facebook, there were several people who contacted some more people and arranged a plan among each other. We met at 12:45pm close to the parliament building [...] The next morning, more people who found additional information on another Facebook group (organized by desperate parents) came and joined us." This unexpected citizen action achieved its apogee on the night between $6^{\text {th }}$ and $7^{\text {th }}$ of June as protesters encircled parliament, blocking MPs and foreign investors from freely exiting. In the following days, according to most media outlets, the size of the crowd in Sarajevo reached 10,000, while other cities from both entities like Mostar, Zenica and Banja Luka joined in protest. Thus, Bebolucija was born as a spontaneous outrage and not as an organized action. At first, protesters only demanded the JMBG issue to be resolved, but in a matter of days, due to the troubling social and economic state of $\mathrm{BiH}$, the protest turned into a spectrum of social demands, the main one being the demand for the resignation of all ministers on cantonal, entity and state levels (symbolized by an action on July 1, 2013 called OTKAZ (Come out and fire them). Even though the protest managed to mobilize many thousands during the first weeks (especially after the JMBG law was adopted) they eventually died out at the beginning of July.

Likewise, the Tuzla uprisings broke out once the wider population decided to join the month-long and fruitless demands of factory workers requesting a resolution of the corrupt post-war privatization that had left many either out of work or without regular (in most cases any) paychecks. ${ }^{5}$ As was the case with Bebolucija, the second uprising erupted out of the blue once Aldin Siranovic, an unemployed citizen of Tuzla, created a Facebook group on Feburary 5 called "50.000 people on the streets for the better future". On the February

4 The demands were particularly relevant bearing in mind the case of Belmina, a little girl that needed JMBG in order to travel abroad for medical treatment and who became the main symbol of the protests. Sadly, she passed away during the protests.

5 Tuzla was the most important industrial centre in $\mathrm{BiH}$ during communist Yugoslavia. Even if the post-war privatization process had affected it, factories left from the communist period still offer the main source of employment in this city. 
6, there were around 6,000 people on the streets and on the $7^{\text {th }}$, with around 10,000 people taking over Tuzla, the unseen destructiveness was witnessed in the city and around the country in ad-hoc protests that arose not only to support Tuzla workers but to denounce a completely dysfunctional state. In such a state of absolute rage, the buildings of cantonal governments in Tuzla, Zenica, Sarajevo, Bihac and Mostar went down in flames. Similarly, in the town of Mostar, two buildings belonging to the main ethno-national parties, SDA (Bosniak) and HDZ (Croat), were put on fire. Also, in the town of Bihac, demonstrators surrounded the house of the cantonal minister, demanding an immediate resignation. The main demand of the protesters - the resignation of ministers on all levels - was partially fulfilled when four cantonal governments were brought down (Tuzla, Sarajevo, Bihac, Zenica). The protests, involving 28 cities, were the biggest to have ever occured in $\mathrm{BiH}$, appearing in areas dominated by both Bosniaks (Tesanj, Srebrenik, Gorazde, Bugojno etc.), Croats (Orasje, Livno etc.), and also in the mixed areas of Mostar, Travnik, Brcko Distrikt and Jajce. Due to both police and societal pressure, there were no major protests in RS, but some groups from this entity started collaborating with their counterparts from $\mathrm{FBiH}$ during and after uprisings (i.e. in Banja Luka and Prijedor).

Furthermore, after several weeks, protesters directed their energy from the streets towards the organization of plenum (citizen assembly), which can be understood as the third step of this two-year-long social mobilization. Plenum, organized in 22 cities around the country, with the idea of serving as some kind of an instrument of direct democracy, functions as a social institution in which citizens can hear each other, discuss political matters, exercise pressure on and monitor the work of elected officials, and commonly elaborate demands which are to be directed towards authorities. The general rule of the plenum is one person one voice, giving everyone the right to speak, and each proposal is decided upon at the end of each session by majority vote. Thus, the plenum emerged as a way for citizenry to enter the space completely occupied by the political elites, attempting to exert influence over political action. Overall, during the plena, citizens elaborated demands that dealt with issues prevalent in BiH democracy: widespread corruption, disrespect of human rights, high wages in the political-administrative sector, bad conditions in health care and education, and high unemployment. Even though the plenum did not develop in RS due to both state and societal pressures, it was nevertheless marked by a multi-ethnic character. For example, in Mostar, participants demanded the constitutionality of Serb (and any other) minority in the HN Canton (which has been rejected by both the Bosniak and Croat elites). Also, groups from some cities in RS became informally involved (such as Social Justice in Prijedor and the Banja Luka Social Center) and started cooperating (and still do so) with their counterparts in FBiH (Radovic, 2016). Likewise, in multi-ethnic cities in $\mathrm{FBiH}$, a plenum has been organized by participants coming from all three ethnic groups. In the town of Travnik, the plenum and protests themselves were symbolically initiated by three students, each belonging to different constitutive peoples. Overall, plenum phenomenon remained active until mid-May 2014, when it was stopped due to the floods which affected great parts of the country, leaving around 100,000 people temporarily displaced. After this, the practice of plenum was only continued in Zenica and Gracanica, while it transformed into informal groups in several cities (Movement for Social Justice in Bihac, Informal Group for Social Justice in Prijedor (RS), Network “5F7” Tuzla) (Milan 2015). 


\section{PROTESTS OF 2013-2014: CONSTRUCTING “THE PEOPLE" AS CITIZENS}

The protests of 2013-2014, without a question, were the most significant social uprising in the modern history of Bosnia-Herzegovina. They were a clear example of the institutional chasm separating people from power (a first precondition for the rise of populism and also a factor leading to some kind of (organic) crisis). Thus, the power to make things done, embodied in political institutions, unable to process rising demands, could no longer be considered in the service of citizens. Institutional unresponsiveness was strikingly clear as, without JMBG, the citizen is unregistered by the state bureaucracy, and as such legally does not exist (Mujkic 2016). More precisely, newborns left without the right to citizenship were concomitantly stripped of any other right (i.e. a passport). As Arendt (1958) states, citizenship is the right to have rights. Consequently, as we could observe during the protests, JMBG or the Tuzla crisis simply pushed the citizens beyond the limit of patience with the existing system, erupting in a country-wide festival of civil disobedience. In both instances, a crisis (crystalizing in JMBG and Tuzla but appearing due to socio-economic conditions) was followed by various protests in both entities (involving war veterans, ecologists, students, pensioners, teachers), as the list of problems to complain about is almost endless in a country in which 60 percent of young people want to migrate (Bljesak 2016), 40 percent lives at or below the poverty line (Slobodna Evropa 2016), the monthly salary of most people moves between 100 and 300 euros (Andrijanic, 2014), most pensions stand below 150 euros (Andrijanic 2014), youth unemployment stands at 57.9 percent (DW, 2014a), corruption reaches the highest levels in Europe, and politicians still make around 2,200 euros per month (DW, 2014a) (way above the regional average, which stands below 1,000 euros). Some of the usual reasons for protests, demonstrating the complete abyss between people and power can be read from the following comments recorded during demonstrations.

"The list of reasons for human rage and frustration is too long" (Ljubanovic 2013); "I have twenty years, I go to university and hope for nothing" (Mrkic-Radevic 2014); "I came here to support people who do not have anything any more, from whom they have taken everything" (ibid); "I have two sons waiting for job, I don't have anything to live for, I just want change" (Tacno 2014); "The movement emerged not as the fruit of hope, but of despair" (Toe 2013).

Thus, the situation created by Tuzla and JMBG served to clearly polarize the public space between citizens and institutions, causing a crisis in a previously dominant type of objectivity. ${ }^{6}$ In this sense, by the simple act of people taking to the streets in protest (creating the appearance of crowds), occupying public spaces, attacking buildings that embody political power and demanding the resignation of those who, for two decades claimed to represent their (ethnic) peoples, the previous narrative that sustained the functioning of an ethno-national regime was challenged, only exacerbating the (minor) organic crisis. ${ }^{7}$

Moreover, an easily understandable and emotional example of abandonment of babies and workers by the state served to clearly demonstrate the standoff between the weakest (babies, workers, and thus ordinary

6 Socio-economic conditions and street demonstrations feed each other in the creation of a crisis. One without the other can't reach the full circle.

7 A true organic crisis can only be recognized a-posteriori. Even if we understand how this was not an exemplary type of organic crisis, we keep using the term for analytical purposes. 
citizens) and the most powerful (the political elites) (Kazaz 2013). Consequently, babies and disenfranchised workers turned into empty signifiers of too many problems affecting the citizens of BiH. Thus, the discourse most elaborated during the protests turned issues of citizenry (due to the clear exemplification of denial of citizenship to babies) into a master signifier of all the issues affecting various sectors of population. In this sense, the JBMG crisis or events that sparked the protests in Tuzla, acquired centrality in public space and their particularities came to signify a total chain of equivalential social demands. Besides, as a heterogeneous mass rose together, it came to embody, by confronting institutions as a unified whole and not as a variety of separate demands, a popular demand. By putting into question well-embedded social objectivities and opening spaces for discourses that up until that point had belonged to the field of discursiveness, and surplus of meaning, protests symbolized a direct announcement of the beginning of politics - that "denunciation of tacit contract of adherence to the established order" (Bourdieu 1991: 127).

Furthermore, by strictly differentiating itself from the previous ethno-nationalist notion, one on whose legacy it nevertheless had to operate, the new discourse proclaimed (in a protest organizer's opening declaration) that the new "people" were to be "We, the citizens of Bosnia-Herzegovina". On the other hand, the "constitutive other" was to become:

"You, the political elites [...] are to blame for the fact that our babies do not have identification numbers. You are to blame that we do not live but survive [...] You need to be in our service, and not we in yours. We do not care if the baby comes from Banja Luka, Mostar or Sarajevo [indicating cities with different ethnic majorities]. To us, you are all equally responsible and guilty" (Buka, 2013b).

In this sense, the new "people" of more inclusive identity, cutting across the plurality of ethnic identities, grounded its very unity in the rejection of corrupt ethno-national elites, making it into an excluded element for rival hegemonic construction. Thus, the new frontier implied a clear division between corrupt political elites and abandoned citizens. Here, the common denominator of people = citizens exemplified (as no other concept could) the absolute outsiders of the BiH ethno-dominated social reality, the system outcasts par excellence, the unrepresented ones, something comparable to Marx's lumpenproletariat or Lacan's caput mortuum (the residue left in a tube after a chemical experiment) (Laclau 2005). Thus, by filling the emptiness of a citizen concept with various diverging social demands, the new discourse cast the citizens of $\mathrm{BiH}$ for the first time as relevant historical actors, bringing them to the center of the political stage and constructing a movement that I would term "citizen populism".

Moreover, by conducting participant observation, informal talks and an analysis of media reports, the trans-ethnic character of the protests was made evident. Thus, during the Bebolucija fieldwork in Mostar and Sarajevo, we could see people from the Bosniak-Muslim-dominant areas (Zenica, Srebrenik, Gradacac, Tuzla, Gorazde, etc.), Croat-dominant areas (Capljina, Ljubuski, Siroki Brijeg, Livno, Tomislavgrad, etc.) and also from Serb-dominant areas (Banja Luka, Bijeljina, Trebinje, Prijedor, etc.). Also, we could witness banners stating "Banja Luka for JMBG", "Banja Luka and Sarajevo: Rise up together", "Antifascist Banja Luka", "Capljina, Ljubuski and Siroki Brijeg for JMBG" (Tacno 2013, Buka 2013d). Also, an informal group of citizens organized protests in Banja Luka showing banners that declared that the "national belonging of our dearest is called a child" and 
(directly responding to Serb politicians who spread misinformation about the occupied parliament), "Stop bullshitting about how you are in danger and do your work! Banja Luka for JMBG" (Buka 2013c). Besides, the official format of JMBG protests defined itself as a "citizen initiative, fighting for the basic human rights of all citizens, confronting nationalism and all other types of discrimination, hoping to establish solidarity among different groups" (Buka 2013).

Likewise, the 2014 uprising was also of a clearly citizen and multi-ethnic character, something confirmed during our fieldwork (mostly in Mostar during participant observation and interviews with Abrasevic ${ }^{8}$ related activists). Similarly, a media content analysis pointed in the same direction. For example, the Mostar plenum invited people to participate "against maintenance of war division lines, and for society based on social justice!" (Bljesak 2014). Also, graffiti showing "Death to Nationalism", "Stop Nationalism", and "Stop to National Divisions" covering the walls of a municipal house in Tuzla, burning in flames, or banners appearing in protest around the country stating "We are hungry in three languages", "Screw you and your three constitutive people", "Our Unity = Your Destruction" clearly defined the identity of those that the protesters were up against.

In this sense, discursive practices of protesters show how citizen populism created a discourse of a country based on the revolutionary-democratic concept of nation, downplaying the previously dominant nationalistic concept. Consequently, the state was to be identified with people as sovereign citizens (Hobsbawm 1993), where all political subjects are to be equal regardless of their ethnicity. Along these lines, denominations given to plenums ("Plenum of Citizens"), or that assigned to the day marking the beginning of protests ("Day of Citizen Courage"), by strictly avoiding any use of national identification and downplaying those who attempted to do so (like the Anti-Dayton group), tried to open up the horizons of non-ethnic bases of solidarity in BiH society. Therefore, a new discourse focused on building social and class solidarity, one that transcends inter-ethnic lines, announcing what Klix (2016) called "times when social justice overcame all divisions". In this sense, the notion of class division, embodied in an empty signifier of "social justice" turned into one of the nodal points of the new narrative. A frank comment from one protester clearly demonstrates this feeling: "This is a real chance for people to realize how we are all in deep shit, all of us, Croats, Serbs and Bosniaks. The thing that connects us is that my generation will not even have pensions, nor free education or healthcare, opportunities for employment, whereas the state will serve only the rich" (Anadolija 2014).

Last but not least, citizen discourse completely changed the meaning of empty signifiers of nation and freedom. In this sense, one of the most visible banners during the protests, stating that "Freedom is My Nation" (coming from an informal group of citizens in Mostar) embodies in the best way the change made to these two signifiers. The sign is a challenge to the dominant discourse's nodal point, "Ethnicity is my Nation", as it replaces the exclusionary notion of ethnicity with freedom - an inclusive category to be claimed by all citizens of the country both on a personal and collective level. In this sense, the wordplay around empty signifiers of freedom and nation introduced a fight over the appropriation of such words by completely different political movements, thus well exemplifying their floating character.

8 Abrasevic is a youth educational and cultural center standing at the ex-war division line. It promotes cooperation among young people of different ethnic backgrounds and it served as a place where the Mostar plenum was held. 
Finally, it can be argued that the institutionalization of Plenum emerged as a case par excellence of what could fit into the notion of citizen populism. In this sense, people did effectively, through the very institution of direct democracy, imagine themselves as nothing more than citizens of a particular state. In this way, by creating an institution of egalitarian citizenship, they completely stripped themselves of an ethnic primacy deeply embodied in the primordial character of ethno-national discourse. As such, the mobilization and plenums that followed, for not emerging from any type of protest organized structurally, developed as a radical action of sovereign citizenry, embodying the case in which plebs claimed to become the new populous. Consequently, by becoming a name (citizens) in its absence, the 2013-2014 protests signified the rise of "Citizen Populism" in $\mathrm{BiH}$. In this sense, "Citizen Populism" appears as a type of contextually specific (Dayton $\mathrm{BiH}$ ) movement phenomenon that: a) embodies a discursive tactic which fills the emptiness of the citizen concept with various issues overwhelming the BiH socio-political space; b) attempts, by constructing "the people" as citizens, to offer a sense of social integration different to the one propagated by an ethno-national project of the social.

\section{THE ETHNO-NATIONAL NARRATIVE FIGHTS BACK}

As was noted in the theoretical framework, any discourse that attempts to institute a new social objectivity must reckon with the resistance to hegemonic narratives that occupy a dominant position in the social space at the time. Thus, the citizen discourse had to successfully challenge a deeply embedded ethnonational one, and to weaken its grip on social reality. In this sense, ethno-national elites tried to perpetuate the type of subjectivity able to maintain the continuity of historical unity that served their interests. Here, ethno-national discourse had as its goal - in order to ensure continuity of its historical bloc - the maintenance of dominance over a citizen's imagination and the perpetuation of ethno-national objectivity.

First of all, ethno-national elites tried to delegitimize the unity of protesters by means of representing them as being in service of the "constitutive other" and thus "against us" - the only true "people". With this in mind, those proclaiming themselves as representatives of the Serb "people" essentially identified the protests as an attempt by unitarists in Sarajevo (the capital of both the $\mathrm{BiH}$ and $\mathrm{FBiH}$ where a majority of population is Bosniak-muslim) to overthrow the Republic of Srpska. For example, the president of the RS entity, Milorad Dodik, while commenting on the blockade of parliament, stated how the protests were organized by Bosniak parties, some foreign embassies, and certain NGOs with the aim of threatening the security of Serbian representatives (Buka, 2013e). He added how Serbian and Croat representatives were held as hostages while Bosniaks could leave the parliament as they pleased (a verified lie) (Kresic 2013). Perpetuating a similar narrative, a newspaper in the RS released a piece with the title on its cover page: "Demonstrators were promised guns for attack on RS!!!" (Prometej, 2014). Similarly, the Serbian representative in parliament, Aleksandra Petrovic, tweeted during the blockade, "Protests in front of the Parliament are the idea of Bosniak parties, aimed at lynching us from RS. The building is surrounded and they are calling on us Serbs" (Bursac 2013). Another representative, Zivkovic, stated how "parliament is being converted into a camp, and we from the RS are the targets" (Buka 2013a). Besides, while commenting on protests in an interview given after the end of crisis, President Dodik concludes how "citizen rights are not an issue, but the real issue is to negate national rights to people that want them" (Kresic 2013). 
Secondly, Croat ethno-national elites and media connected to them followed a similar line of thought. Thus, Nino Raspudic, an academic connected to the regime, proclaimed how "protest is a Bosniak spring! Croats will not join" (Prometej 2014). At the same time, Dragan Covic, president of the most important party claiming to represent the interests of the Croat people (HDZ BiH), affirmed how protests represent a "wish to make a unitary Federation of Bosnia-Herzegovina which would finally convert it into an entity of the Bosniak people, just like the RS is an entity of the Serbian people" (Prometej 2014). The webpage Poskok.info constructed a similar narrative, claiming how protests represent "Greater-Bosniak politics and as such are a faithful copy of GreaterSerbian politics from the end of 1980s" (Prometej 2014). At the same time, the newspaper daily Vecernji List emphasized how protests and plenums that followed are essentially in the service of Bosniak politics, making an argument that overwhelmingly emphasized setting on fire the government and party buildings situated on the "Croat side" of Mostar. ${ }^{9}$ By choosing to ignore similar damage done to properties belonging to the Bosniak ethno-parties on the "Muslim side" of the city, the newspaper aimed to forge an environment of fear and interethnic conflict, a powerful method in a city that still hadn't healed its war wounds.

Thirdly, Bosniak representatives have likewise propagated an ethno-national discourse of fear and hate. Thus, SDP proclaimed how protests are "well-planned operations against the country of Bosnia-Herzegovina, organized by SANU (the Serbian Academy of Sciences and Arts - in the past connected with propagating ideas of Greater Serbia), and in no way represent protests of socially endangered citizens" (Prometej 2014). The president of the same party, Zlatko Lagumdzija, claimed how protesters wanted to establish a third entity of Croat people (referring to an idea about the Croatian part of the country that would separate from $\mathrm{FBiH}$ ) (Prometej 2014). At the same time, the webpage drmaj.ba created an explanation stating how "considering the Western factor, this smells of pro-Greater-Croatia intervention" (Prometej 2014).

Therefore, ethno-national elites, frightened by the cracks appearing in the regime they had successfully established by the end of the civil war, tried to divert from the real significance of the protests by propagating the well-embedded notions of fear and hate, thus perpetuating once again the "civil wars of memory" in the hope of maintaining an ethno-national logic as the only relevant embodiment of BiH reality.

\section{PROTESTERS RETREAT, ETHNO-NATIONAL HEGEMONY CONTINUES (BUT CRUMBLING?)}

By the late spring of 2014, protests, and the plenums that followed, had lost the energy that had characterized them before. According to our informants, the idea of the plenum was partially usurped by agents of the political class and by the fact that plenum failed to show any real progress or effects on the political stage. The reasons for failure are many, but most of them lie in the fact that the equivalential chain of demands could not be sufficiently expanded in BiH society at the time, making that necessary critical mass of people, or the fight over social majorities, a failed task of the protesters. In any case, it would be difficult to expect subjectivity in $\mathrm{BiH}$ to change so drastically and rather quickly after so many years of absolute hegemony of ethno-national discourse. However, resistance offered by the citizen discourse, coming at times of crisis, still must be rightly characterized as the most important social awakening and challenge to ethno-nationalism in

9 Mostar, once a multicultural city with a high rate of inter-ethnic marriages, was effectively divided during the war into Bosniak and Croat sides (a division that has been effectively kept until now). 
the short history of an independent and procedurally democratic BiH.

First of all, it cannot be denied that chains of the ethno-national narrative still proved unbreakable to many. Thus, as time progressed, various demonstrations that were happening outside of areas with a BosniakMuslim majority found themselves obliged to create a clear distance from anything happening in the so-called political Sarajevo. In this sense, student protesters in Banja Luka (the capital of the RS) made sure to clarify how they were in no way connected to movements happening in other entity. Marking their territory clearly with RS flags, they decided to play on the terrain established by the dominant ethno-national discourse. However, it is important to note how Nikola Dronjak, the leader of the protests, recognized that students avoided identification with the wider BiH protests out of fear that the government would scapegoat them as the enemies of the RS (Bursac 2013a). Nevertheless, Dronjak declared how unemployment, criminality and corruption, together with economic and social misery were the common denominators of all citizens of BiH. Similarly, in the city of Mostar, many of those that otherwise found reasons to announce their dissatisfaction with the current state of affairs, did believe in the narrative of the Bosniak spring, only showing themselves reluctant to unite with those who are not "us". Additionally, the existence of social fear and police repression was another major factor in play. For example, local police strictly prohibited demonstrators from crossing warseparation lines or to enter the "Croat" side of the city, so as to avoid "mixing".

Secondly, upon explaining anything that goes in $\mathrm{BiH}$, one cannot avoid taking into account that the main engine of the economy and the main employer in this country is public administration, accounting for about $55-65 \%$ of total GDP (Zelenika 2014). Out of the total number of about 720,000 people working in BiH, around 240,000 of them are employed in institutions, firms and agencies in state ownership (BHAS 2016). Besides, a striking level of unemployment (around 45\%, youth unemployment being at 60\%) (UNDP 2016), only exacerbates the power of ethno-national parties that hold the sources of survival. In this sense, a social structure in which a professional middle class hardly exists, and where most jobs are obtained through party membership understandably paves the way for the patrimonialization of relations between those controlling companies (political parties) and their client-employees (the citizens) (Stipic 2017). Pairing this with the fact that BiH can be understood as what Zizek terms a "society of general permissibility" (Zizek in Blagovcanin 2013), the arbitrariness that reigns in this polis increases the factor of fear and its influence over social behaviour. This factor can, to a large extent, explain the behaviour of some social groups. By enjoying a certain life stability, the middle-class employed in the public sector preferred not to join the protests, thus accepting the existing institutional framework as being preferable to undertaking actions which it considered threatening for its current standing in society. As Emir Fetahovic, a protester and plenum organizer from Travnik notes, in BiH "fear is stronger than the desire for a better life [...] as many people are afraid to join the movement because in one way or another, they are somehow dependent on the power structure, fearing that either they or their family member could lose the job and have problems" (DW 2014).

Moreover, a third major reason that has strongly determined the fate of the movement has been the unwillingness of protesters to connect, cooperate or be associated with any kind of party. In this sense, an official proclamation of JMBG protest organizers stated how "Politicians and political parties have nothing to 
offer to us" (Buka 2013). Also, one of the main organizers stressed that "the first imperative of this mobilization was to avoid the interference of any organization or party" (Toe 2013). Such a decision obviously came about as a result of a citizen character that protesters were aiming to construct, and was likewise most definitely influenced by the disillusionment people felt towards any kind of party or organization. While such an attitude towards politicians and parties that were in office for years and did not do anything is unsurprising and well deserved, this behaviour was no different even towards those parties determined to deconstruct ethnonational narratives and that proclaim themselves as citizen aggrupation. As Denis Gratz of "Nasa Stranka" (Our Party) ${ }^{10}$ noted at the time: "they (the protesters) were obsessed by the fear that some party could exploit them. A naive, if understandable, position. I have deep respect for citizens who are protesting, but there is one thing that unfortunately they do not understand: putting all parties into the same cauldron is a dangerous game. Most protesters are young people who do not even vote. But the politicians in power in Bosnia and Herzegovina have been there for twenty years, and the only way to send them home is to beat them in the elections" (Toe 2013). In this sense, protesters, which appear as crowd when taking to the streets can hardly expect to make their voices heard without some kind of more organized movement that could offer them direction and representation at higher levels of political decision making (something that can't be done by Plenum). As Dean (2016: 26) notes, while a "crowd provides an opportunity for the emergence of a political subject", the "perspective which gives body to the political subject is the party" (ibid:149). As political experience shows, radical movements cannot simply avoid the state, because being the alternative to seizing or abandoning the state a false one; the real challenge remains in transforming the state itself (Zizek in Dean 2016: 149-150). In this sense, it is rather naïve that $\mathrm{BiH}$ politicians, at least the ones holding power at the moment, will voluntarily and on the advice of citizens, proceed with the recognition of demands as legitimate and change the type of behaviour they have been practising for decades. Thus, as the state presents a barrier to political change, gaining control of the state remains an important goal. It is difficult, at least in terms of current institutional structures of most political regimes that such control could come from any other point than through party politics. It seems to me that the electoral success of parties like Syriza or Podemos, even if certainly not free from deserved criticism and unresolved issues, present a possible direction to take. As Dean (2016: 250) notes, "anyone who is unwilling to talk about the party should not talk about political transformation". Thus, while society and politics in $\mathrm{BiH}$ remain separate universes, an idea cherished by some that things will change for good without direct political engagement seems rather delusional.

\section{CONCLUSIONS AND FINAL REMARKS}

The present article had as its central interest the struggle over identity formation in present-day BiH and its effects on the creation of a specific political situation in this country. In order to investigate my topic of interest, a theoretical framework was constructed by combining discourse theory with those of hegemony and populism. While discourse theory is chosen as it predominantly can explain the construction of social reality, hegemony serves as an explanation of why a certain social order comes to be considered so natural that it represents a consensus on the meaning of the social. Additionally, populism explains the process of 
contestation over the identity of "the people", whose construction, in being the most invoked subject in the history of modernity, becomes a political operation par excellence.

The $\mathrm{BiH}$, ever since the end of the civil war and the beginning of Dayton history dominant ethnonational discourse, resulting from a movement denominated as ethno-national populism, has over-determined subjects in such a way that it has reached the position of a hegemon, effectively closing other possible political and discursive opportunities. As such, it has stabilized power relations around the imagined social totality defined by strong nationalism, authoritarianism and anti-pluralism, converting "the people" into nothing more than instrumentalized ethno subjects, while making ethnic identity the principle political identity in BosniaHerzegovina.

Nevertheless, the protests of 2013-2014, serving as a clear example of the institutional chasm separating people from power, led to the movement that we define as "citizen populism". Appearing at times of a minor organic crisis, citizen populism aimed at creating a new conception of "the people". As such, it caused a crisis in the type of objectivity propagated and established by the ethno-national narrative, opening a way to struggle over the name of "the people" and announcing the first real beginning of politics in the short history of this country. Here, the protesters, by rejecting the notions of the old and embedded BiH political identities, opened a way towards cognitive subversion and a suspension of adherence to the dominant subjectivity, thus "announcing the possibility of changing the social world by changing its representation" (Bourdieu 1991: 128). In this sense, the new "people" - the citizens of $\mathrm{BiH}$ - of more inclusive identity, cutting across the plurality of ethnic identities, grounded its very unity in rejection of the corrupt ethno-national elites, bringing the citizens, system outcasts par excellence (now destined to form the new people), to the centre of the political stage, thus forging a previously unimaginable interpretation of $\mathrm{BiH}$ social reality.

Unfortunately, protests and plenums that followed them in the end somehow deflated and eventually lost the war of position, or the battle over social majorities. As we conclude, the biggest problem resulted from the fact that an equivalential chain of demands could not be sufficiently expanded in BiH society at the time, making the necessary critical mass of people a failed task of the protesters. One of the reasons for people not to join the mobilization was that the chains of the ethno-national narrative still weighed too heavy over many. Besides, patrimonialization of the bureaucratic office, with its enormous power to discipline, had an effect of keeping middle classes away from the protests. Last but not least, protesters made the mistake of rejecting some kind of cooperation with parties that follow similar citizen narratives, forgetting that the state in current institutional arrangement presents a real barrier to political change.

Nevertheless, it is important to note, despite some criticism given, that the social movements of 20132014 have signified the single most important political moment in the history of Dayton BiH. As such, once placed in the specific socio-political and historical context of BiH democracy, the importance of trans-ethnic character of these protests cannot be overstated. Thus, the protests, introducing concepts of common purpose and solidarity between ethnic groups and replacing the notion of "vital national interest" with that of "social justice", have to be praised for even beginning to change the framework of understanding BiH reality. In this sense, the new construction of "the people", exemplified through the discursive practice of protesters and 
by the institutionalization of Plenum, represented the most democratizing possible act as it effectively, if only partially and for a brief moment, managed to convert ethno-national subjects into fully-fledged citizens. If nothing else, there is a great hope that the protests can serve as a school for the future.

Finally, it seems indispensable to think about how, taking into account the BiH example and CEE perspectives, "in a world where barely 10 out of 180 nations can with conviction affirm that their citizens in any kind of real sense belong to one ethnic or language community, nationalism (or nationalist populism) based on creating such homogeneity is not only undesirable, but is to a great extent auto-destructive" (Hobsbawm 1993: 202). In this sense, other types of more progressive populisms may offer a chance for different political paradigms in times of crisis. 


\section{REFERENCES}

Abazović, D. (2006) Za naciju i Boga. Sarajevo: Univerzitet u Sarajevu.

Althusser, L. (1984) Essays on Ideology. Nortfolk: Verso.

Andrijanic, Z. (2014) Prosvijedi bi mogli dovesti do sloma Federacije. Vecernji List. Available at www.vecernji.ba/vijesti/prosvjedi-bimogli-dovesti-do-sloma-federacije-915415 [Accessed: 02-04-2017].

Arendt, H. (1958) The origins of totalitarianism. New York: Meridian Books. https://doi.org/10.1057/9781137382245.0006

Banjalučani podržali sarajevske proteste, u petak organizovan prevoz u Sarajevo. (2013c) Buka. Available at www.6yka.com/ novost/39401/banjalucani-podrzali-sarajevske-proteste-u-petak-organizovan-prevoz-u-sarajevo [Accessed: 10-04-2017].

Bates, T. (1975) Gramsci and the Theory of Hegemony. Journal of History of Ideas, 36: 351-366. https://doi.org/10.2307/2708933

BHAS (2016) Agencija za Statistiku Bosne i Hercegovine. Available at www.bhas.ba/ [Accessed: 01-03-2017].

BiH u Europi prednjači po nezaposlenosti i odlivu mozgova. (2016) Bljesak. Available at http://bljesak.info/rubrika/business/clanak/ bih-u-europi-prednjaci-po-nezaposlenosti-i-odlivu-mozgova/178904 [Accessed: 01-04-2017].

Blagovcanin, P. (2013) Bajtal, Mujkic, Markovina: Fra Ivu Markovica mrze jer odbija da mrzi. Tacno. Available at www.tacno.net/ sarajevo/bajtal-mujkic-markovina-fra-ivu-markovica-mrze-jer-odbija-da-mrzi/ [Accessed: 04-04-2017].

Bosna i Hercegovina i dalje „šuti i trpi“. (2014a) DW. Available at www.dw.com/hr/bosna-i-hercegovina-i-dalje-\%C5\%A1uti-itrpi/a-17342059 [Accessed: 01-04-2017].

Bosnia-Herzegovina country info. UNDP (2016) Available at www.ba.undp.org/content/bosnia_and_herzegovina/en/home/ countryinfo.html [Accessed: 10-03-2017].

Bourdieu, P. S. (1991) Language and Symbolic Power (Raymond, G. - Adamson, M. Trans.). Cambridge: Polity Press. (Originally published 1982). https://doi.org/10.1017/s004740450001705x

Bursac, D. (2013) Terapijsko skidanje naroda sa sisanja vesla. Accessed 12.10.2017. Retrieved from www.6yka.com/novost/39609/ dragan-bursac-terapijsko-skidanje-naroda-sa-sisanja-vesla [Accessed: 12-10-2017].

Bursac, D. (2013a). Nikola Dronjak: Vi tuzite mene, ali I Predsjednika Dodika! Available at www.6yka.com/novost/39975/nikoladronjak-vi-tuzite-mene-ali-i-predsjednika-dodika [Accessed: 12-10-2017].

Dean, J. (2016) Crowds and Party. London: Verso.

Demonstranti: Politicarine treba nam vasa podrska, necete nas prevatriti i zaustaviti. (2013b). Buka. Available at www.6yka.com/ novost/39495/demonstranti-politicari-ne-treba-nam-vasa-podrska-necete-nas-prevariti-i-zaustaviti [Accessed: 11-10-2017].

Dvije godine poslije: Vrijeme kada je socijalna Pravda nadmasila sve podjele (2016) Klix. Available at www.klix.ba/vijesti/bih/dvijegodine-nakon-protesta-vrijeme-kada-je-socijalna-pravda-nadmasila-sve-podjele/160205130 [Accessed: 22-03-2017].

Foto galerija: Dani ponosa: JMBG protesti u Sarajevu i Mostaru. (2013) Tacno. Available at www.tacno.net/muzika/jmbg-protesti-usarajevu-i-mostaru/ [Accessed: 11-10-2017].

Galvan, I. E. (2011) La lucha por la hegemonia durante el primer gobierno del MAS en Bolivia (2006-2009): un analisis discursivo. Tesis Doctoral. Available at http://eprints.ucm.es/14574/1/T33089.pdf [Accessed: 10-03-2017].

Guzina, D. (2005) How Multiethnic is Democracy in the Balkans: The Case of Bosnia. Paper presented at the annual meeting of the International Studies Association, Hilton Hawaiian Village, Honolulu, Hawaii. Available at: www.allacademic.com/meta/ p70760_index.html [Accessed: 23-04-2012].

Habermas, J. (1996) The European Nation-State - Its achievements and Its Limits. On the Past and Future of Sovereignty and Citizenship. Ratio Juris, 9: 125-137. https://doi.org/10.1111/j.1467-9337.1996.tb00231.x

Hobsbawm, E. J. (1993) Nacije i Nacionalizam (Cengic, N. Trans). Zagreb: Novi Liber. (Originally Published 1990).

Husremovic, D. Z. - Powell, S. - Šišić, A. - Dolić, A. (2007) Obrazovanje u Bosni i Hercegovini: Cemu ucimo djecu? Analiza sadrzaja udzbenika nacionalne grupe predmeta. Fond otvoreno drustvo BiH. Available athttp://www.erisee.org/downloads/2013/2/bh/ Analysis\%20of\%20teaching\%20books\%20for\%20national\%20subjects\%202007\%20BH.pdf [Accessed: 10-05-2017].

Jorgensen, M. - Phillips, L. J. (2002) Discourse Analysis as Theory and Method. London: Sage Publications. https://doi. org/10.4135/9781849208871

Ivancic, Z. (2013) JMBG Protesti: Dnevnik Aktiviste. Available at: www.media.ba/bs/magazin-mreze-i-web/jmbg-protesti-dnevnikaktiviste [Accessed: 07-10-2017].

Kazaz, E. (2013) Bebolucijom Protiv Mocnika. Available at: www.6yka.com/novost/40091/enver-kazaz-bebolucijom-protiv-mocnika [Accessed: 15-04-2017]. 
Kresic, Z. (2013) Prosvjede je potaknuo SDP. Vecernji List. Available at www.vecernji.ba/prosvjede-je-potaknuo-sdp-567273 [Accessed: 02-03-2012].

Kuljić, T. (2005) Kritička kultura sećanja. Beograd: Fondacija Friedrich Ebert.

Laclau, E. (2005) On Populist Reason. London: Verso.

Ljubanovic, D. (2013) Njihovo velicanstvo vlast. Buka. Available at www.6yka.com/cyr/novost/40017/njihovo-velicanstvo-vlast [Accessed: 01-04-2017].

Milan, C. (2015) "Sow hunger, reap anger". Grassroots protests and new collective identities in Bosnia-Herzegovina. Heinrich Boll Stiftung. Available at: https://pl.boell.org/sites/default/files/uploads/2015/04/protests_bch_milan_en.pdf [Accessed: 01-102017].

Milorad Dodik: Sjednice Vijeca ministara BiH odrzavati van Sarajeva (2013e) Buka. Available at www.6yka.com/novost/39637/miloraddodik-sjednice-vijeca-ministara-bih-odrzavati-van-sarajeva [Accessed: 12-10-2017].

Mouffe, C. (2005) On the Political. Cornwall: Routledge.

Mrkic-Radevic, B. (12.02.2014) Nisu nasa djeca govna da ih Bacaju u Miljacku. E-Novine. Available at www.e-novine.com/mobile/ region/region-bosna/98783-Nisu-naa-djeca-govna-bacaju-Miljacku.html [Accessed: 27-03-2017].

Mujkic, A. (2006) Etno-politicki diskurs Etnopolisa. Godisnjak Fakulteta Politickih Nauka, 1 : 66-84.

Mujkic, A. (2016) Bosnian Days of Reckoning: Review of the Sequence of Protests in Bosnia and Herzegovina 2013-14, and Future Prospects of Resistance. Southeastern Europe, 40: 217-242. https://doi.org/10.1163/18763332-04002004

O’Donnell, G. (1994) Delegative Democracy. Journal of Democracy, 5: 55-69. https://doi.org/10.1353/jod.1994.0010

Okvir djelovanja JMBG pokreta (2013) Buka. Available at www.6yka.com/novost/41295/okvir-djelovanja-jmbg-pokreta [Accessed: 1005-2012].

Perica, V. (2002) Balkan Idols: Religion and Nationalism in Yugoslav States. New York: Oxford University Press. https://doi.org/10.1093/0195148568.001.0001

Perišić, N. (2010) Monolitne naracije i opsesija (etničkom) pripadnošću. In Puhalo, S. - Petovic, N. - Petrisic, N. (eds.) Spremnost na pomirenje u Bosni i Hercegovini. Sarajevo: Friedrich Ebert Stiftung, 67-146.

Plenumi i protesti sirom BiH (2014) Tacno. Available at www.tacno.net/novosti/plenumi-i-protesti-sirom-bih/ [Accessed: 26-03-2017].

Prosvijedi u Mostaru traju vec mjesec dana: Plenum poziva gradane na prosvjednu setnju. (2014) Bljesak. Available at www.bljesak. info/rubrika/vijesti/clanak/prosvjedi-u-mostaru-traju-vec-mjesec-dana-plenum-poziva-gradane-na-prosvjednu-setnju/78655 [Accessed: 12-10-2017].

Protesti građana: Zahtjevi ovih ljudi su donji prag dostojanstva. (2014) Anadolija. Available at www.6yka.com/novost/51335/protestigradana-zahtjevi-ovih-ljudi-su-donji-prag-dostojanstva [Accessed: 10-14-2017].

Protesti u Sarajevu zavrseni: Hiljade ljudi ispred Parlamenta BiH. (11.06.2013d) Buka. Available at: www.6yka.com/novost/39615/ protesti-u-sarajevu-zavrseni-hiljade-ljudi-ispred-parlamenta-bih [Accessed: 11-10-2017].

Protestni pokret u Travniku (2014) DW. Available at www.dw.com/bs/protestni-pokret-u-travniku/a-17453437 [Accessed: 29-03-2017].

Radovic, N. (2016) Supporting informal citizens' groups and grass-root initiatives in Bosnia and Herzegovina. Ludwig Boltzmann Institute of Human Rights and Research Association. Available at http://bim.lbg.ac.at/sites/files/bim/attachments/supporting informal_civic_groups_interim_report_jan_2017.pdf [Accessed: 05-10-2017].

Stipic, I. (2017) Ethno Bureaucratic Patrimonialism: The Political Regime of Bosnia-Herzegovina. POLIS, 16: 91-116.

Teorije zavjere- Što se sve reklo o protestima u BiH. (2014) Prometej. Available at www.prometej.ba/clanak/bezdan-doziva-bezdan/ teorije-zavjere-sto-se-sve-reklo-o-protestima-u-bih-1454 [Accessed: 27-03-2017].

Toe, R. (2013) Bebolucija: Spring Delayed. Balcanicacaucaso. Available at www.balcanicaucaso.org/eng/layout/set/print/content/view/ print/138840 [Accessed: 01-04-2017].

Usvojena informacija Vlade RS, trazi se odgovornost bezbjednosnih struktura. (2013a) Buka. Retreived from www.6yka.com/ novost/39794/usvojena-informacija-vlade-rs-trazi-se-odgovornost-bezbjednosnih-struktura [Accessed: 12-10-2017].

Verbalni 'građanski rat' u BiH. (2016) Slobodna Evropa. Retreived from www.6yka.com/novost/117272/verbalni-gradanski-rat-u-bih [Accessed: 02-04-2017].

Zelenika, P. (2014) Svaki treci zaposlenik u BiH radi u javnoj upravi. Vecernji List. Retrieved from www.vecernji.ba/svaki-trecizaposlenik-u-bih-radi-u-javnoj-upravi-954862 [Accessed: 15-03-2017]. 